\title{
Preface and acknowledgment
}

In today's interdependent world society, lessons in development should be viewed as a global public good, with success stories objectively assessed and widely circulated. A century of development in Taiwan is unique not only in economic but also socio-political terms. In fact, Taiwan's transformation from a subjugated colony to a culturally rich, economically prosperous and politically progressive democracy is often overshadowed by its economic development from an agrarian economy to the high-tech hub of Asia.

The "Enlightenment Movement" in the 1920s, exemplified by the establishment of the Taiwan Cultural Association and the movement of a "Petition of Establishing Taiwan Parliament" is arguably a historical turning point in Taiwan's modernization. After numerous setbacks, both movements precipitated a series of social and political transformations that stoked Taiwanese self-consciousness, autonomy, and self-determination during the Japanese empire period. Despite subsequent repressive governance under the authoritarian regime in post-World War II, the Taiwanese nurtured distinct cultural, ethnic, and national identities, as well as strong democratic ideals in their struggle for nation-building.

This book offers a critical review of the development of socio-cultural, economic, and national identity in Taiwan in the twentieth century and beyond. It is hoped that exploration of Taiwan's development as a modern, industrialized democratic country will offer a compelling model of development across multiple academic disciplines and important policy implications in world development. This edited volume reflects the collective wisdom and in-depth research of distinguished scholars in diverse areas of Taiwan study.

I would like to express my sincere gratitude to each author for their diligent research and writing, as well as numerous anonymous referees for constructive reviews on the manuscript. In addition, special thanks are due to Edward Friedman and Masahiro Wakabayashi for writing the foreword essays. The publication grant from Taiwan Foundation for Democracy and the Tsao Yun Ho Foundation is greatly appreciated. Of course, the views expressed in each chapter belong solely to each author and do not represent those of the funding institutions. As always, I want to thank all members of my family for their 
ongoing support, particularly through my final edits during the COVID-19 pandemic.

Peter C.Y. Chow

March 31, 2021
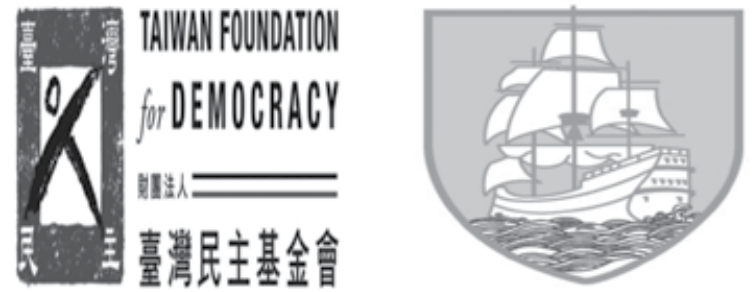